Identification of growth hormone ... (Raden Roro Sri Puji Sinarni Dewi)

\title{
IDENTIFICATION OF GROWTH HORMONE GENE OF Pangasionodon hypophthalmus
}

\author{
Raden Roro Sri Pudji Sinarni Dewi ${ }^{*}$, Agus Oman Sudrajat**), \\ Alimuddin*), and Komar Sumantadinata*) \\ *) Research Institute for Freshwater Fish Breeding and Aquaculture, Sukamandi \\ ${ }^{* *}$ Department of Aquaculture, Faculty of Fisheries and Marine Science, Bogor Agricultural University
}

\begin{abstract}
Identification of growth hormone (GH) gene in a target fish is the first step in the construction of "all fish genes transfer vector" to generate transgenic fish. The research was done to identify and characterize the $\mathrm{GH}$ gene of Pangasionodon hypophthalmus. There were several activities performed in identifying the GH gene: RNA extraction, cDNA synthesis, PCR amplification, and DNA fragment isolation. The characterizations were done using the nucleotide sequencing engine ABIPRISM 3100. The results were then analyzed using BLASTN/P and GENETYX version 7 program. The full- length GH gene of P. hypophthalmus was $1151 \mathrm{bp}$ in length, coding for an open reading frame (ORF) of $603 \mathrm{bp}$. The $5^{\prime}$ and $3^{\prime}$ untranslated regions of the $\mathrm{GH}$ gene were $22 \mathrm{bp}$ and $526 \mathrm{bp}$ long, respectively. The GH gene of P. hypophthalmus had some common characteristics that are owned by GH genes, such as single tryptophan residue (W) on the $104^{\text {th }}$ amino acid, 5 cysteine residues (C) on the amino acid 71 , $135,173,190$, and 198 and a motif of Asn- Xaa- Thr on C terminus which is the potential location for N-linked glycosilation. Polyadenylation signal (aataaa) was on the $14 \mathrm{bp}$ at the upstream of polyadenylation location. Growth hormone of P. hypophthalmus consisted of over 200 amino acids from GH cDNA deduction. The highest proportion of amino acid composition was leusin (14\%) while the lowest was tryptophan $(0.5 \%$.
\end{abstract}

\section{KEYWORDS: Pangasionodon hypophthalmus, GH gene, identification,} characterization

\section{INTRODUCTION}

Growth hormone (GH) is a polypeptide of fundamental importance for growth regulation in vertebrate (Meier et al., 2006). Pituitary growth hormone, also known as somatothropin in fish, is the key protein responsible in the regulation of somatic growth and many aspects of metabolic processes detected in all vertebrate (Ryynanen \& Primmer, 2006). In fish, growth hormone is involved in numerous physiological processes including ionic balance, lipid and protein metabolism, growth, reproduction, and immune function as well as various aspects of behavior (reviewed by PerezSanchez, 2000). Since GH is commercially important in the areas of medicine, animal husbandry, aquaculture, and animal feed formulation, the gene coding for the hormone has been studied extensively in several mammalian and piscine species (Anathy et al., 2001).

In the last twenty years, development of gene transfer was technologically intended to obtain fishery products with certain desired characteristics. Transgenesis or DNA recombinant technology is a genetic engineering that allows the recombination or reunification of

\# Corresponding author. Research Institute for Freshwater Fish Breeding and Aquaculture, Jl. Raya Sukamandi No.2, Subang 41256, West Java, Indonesia. Tel.: +62 260520500

E-mail address: wiewie_thea@yahoo.com 
genes from different sources by in vitro, which then will be introduced to an individual. Genes that have undergone this recombination are called recombinant genes or foreign genes. Gene that is introduced or called transgene is a certain encoding protein that controls a desired character.

At this time, the most successful transgene and the first used in the cultivation of fish for human consumption contains construction of $\mathrm{GH}$ genes. The reason is that the construction of growth hormone can improve growth substantially on a wide variety of fish species such as common carp and gold fish (Cyprinus carpio and Carrasius auratus gibelio) (Zhu, 1992), channel catfish (Ictalurus punctatus) (Dunham et al., 1987), tilapia (Oreochromis niloticus) (Martinez et al., 1996), Atlantic salmon (Salmo salar) (Du et al., 1992), coho salmon (Oncorhynchus kisutch) (Devlin et al., 1994), rainbow trout (Oncorhynchus mykiss) (Devlin et al., 2001), mud loach (Misgurnus mizolepis) (Nam et al., 2001), and Arctic charr (Salvelinus alpinus) (Pitkanen et al., 1999).

Indonesia has many species of fish that have been successfully cultivated. Among various species of potential freshwater fish for commercial cultivation is Pangasionodon hypophthalmus which is culturally special for several consumers, especially in Sumatra and Kalimantan (Nasution et al., 1997). Development of fish culture technology encourages the spreading of $\mathrm{P}$. hypophthalmus products, especially seed to other areas such as Java.

To improve the efficiency of $P$. hypophthalmus culture in Indonesia, it is necessary to develop a transgenesis technology to produce superior broodstocks with fast growth (supergrowth) character in order to increase the culture efficiency on feed, energy and cost. As a first step to produce $P$. hypophthalmus supergrowth, the research was conducted with the aim to identify gene encoding growth hormone $(\mathrm{GH})$ in $\mathrm{P}$. hypophthalmus.

\section{MATERIALS AND METHODS}

\section{RNA Extraction}

Identification of the $\mathrm{GH}$ gene expression was carried out by extracting RNA from organ tissues of pituitary, muscle, brain, liver, testes, and lymph. About $25-50 \mathrm{mg}$ of tissue sample was stored in a sample vial (Eppendorf containing $200 \mu \mathrm{L}$ isogen). Tissue was destroyed using pestle which was previously sterilized with DEPC 1\% Isogen was added into the Eppendorf to a final volume of $800 \mu \mathrm{L}$. Two hundred microliter of chloroform was added and solution was centrifuged with a speed of $12,000 \mathrm{rpm}$ for five minutes at room temperature. Supernatant was then transferred to a new eppendorf containing $400 \mu \mathrm{L}$ isopropanol. Solvent was then centrifuged with a speed $12,000 \mathrm{rpm}$ for 15 minutes at a temperature of $4^{\circ} \mathrm{C}$. Pelleted RNA was kept in the Eppendorf, and the liquid in it was removed. One $\mathrm{mL}$ of $70 \%$ cold alcohol was added into the Eppendorf and then centrifuged with a speed $12,000 \mathrm{rpm}$ for 15 minutes. Pelleted RNA was dried by removing solution in the eppendorf. Pelleted RNA was dissolved by adding $30 \mu \mathrm{L} 1 \%$ DEPC. Concentration of total RNA was measured using a gauge concentration RNA/ DNA (GeneQuant). Absorbance was measured at wavelength of 260 and 280

\section{cDNA Synthesized}

The RNA samples were added with DEPCtreated water to reach a volume of $25-30 \mu \mathrm{L}$ in an RNase- free micro- centrifuge tube. The mixture was heated at $65^{\circ} \mathrm{C}$ for 10 minutes, and then chilled in ice cubes for 2 minutes. During the chilling process, two beads were visible in the bottom of the tube of first- strand reaction mix beads (white tube). If necessary, the tube can be gently tapped against a hard surface to bring the beads to the bottom. RNA solution was then transferred to the tube of first-strand reaction mix beads (do not mix). Three microliters of 'dT3' RACE- VECT “' 5 '- gta ata cga ctc act ata ggg cac gcg tgg tcg acg gcc cgg gct ggt ttt ttt ttt ttt ttt ttt- $3^{\prime}$ ) with concentration of $1 \mu \mathrm{g} / 3 \mu \mathrm{L}$ was added to reach a final volume of $33 \mu \mathrm{L}$. Those samples were kept at room temperature for approximately 1 minute. The contents were mixed by gently vortexing, or by repeatedly pipetting the mixture up and down. To collect the content at the bottom of the tube, the mixture was centrifuged briefly and incubated at $37^{\circ} \mathrm{C}$ for 60 minutes. The completed first- strand reaction was ready for PCR amplification.

\section{PCR Amplification}

One micro liter of cDNA was used as a template for PCR, and then mixed with $1 \mu \mathrm{L}$ FGHP primer (5'- tca gag aga ttt ggc aaa atg gct- 3 '), $1 \mu \mathrm{L}$ RGHP primer (5'-taa tgc aag aat tag ctt 
tat 3 '), $1 \mu \mathrm{L}$ dNTP, $1 \mu \mathrm{L}$ Ex Taq buffer, $0.05 \mu \mathrm{L}$ Ex Taq polymerase (TAKARA) and added with SDW to reach a final volume of $10 \mu \mathrm{L}$. PCR was performed with program: $94^{\circ} \mathrm{C}$ for 3 minutes; $94^{\circ} \mathrm{C}$ for 30 seconds, $59^{\circ} \mathrm{C}$ for 30 seconds, $72^{\circ} \mathrm{C}$ for 1 minute of 35 cycles, $72^{\circ} \mathrm{C}$ for 3 minutes and $4{ }^{\circ} \mathrm{C}$ (unlimited). Observation of PCR amplification was carried out with electrophoresis using $0.7 \%$ agarose gel.

\section{DNA Fragment Purification}

DNA fragment, which was resulted from the PCR analysis was isolated from the gel using Mobio Ultra Clean ${ }^{\mathrm{TM}} 15$ DNA Purification kit (MoBio Laboratories, CA, USA). Weight of agarose gel band slice was determined in a 1.5$2.0 \mathrm{~mL}$ tube. A half volume of ultra TBE Melt and 4.5 volume of ultra salt were added and mixed well. The mixture was incubated at $55^{\circ} \mathrm{C}$ to melt the agarose gel. Ultra bind was resuspended by vortexing at highest speed with ultra bind tube in a horizontal position until homogeneous. Ultra bind was added to the mixture. Incubation was done for 5 minutes at room temperature. The mixture was centrifuged for 5 seconds. Supernatant was removed and set aside. The pellet was resuspended in $1 \mathrm{~mL}$ of ultra wash by vortexing for 5-10 seconds.
The mixture was then centrifuged for 5 seconds and then the supernatant was discarded. The mixture was centrifuged again for $5 \mathrm{sec}$ onds. To remove all traces of ultra wash, as pirating was done with a narrow pipette tip. The pellet was resuspended in water. After that, incubation was done for up to 5 minutes at room temperature followed by spinning the mixture for 1 minute. The supernatant was then removed immediately and transferred to a new tube. DNA was ready to be used.

\section{cDNA Sequencing and Data Analyzes}

Sequencing was done on GH cDNA using automatic ABI Prism machine 3100. Nucleotide and amino acid sequence of P. hypophthalmus GH cDNA were compared with the database in the Gene Bank with the BLASTN/P program. Alignment and the percentage of amino acid similarity were analyzed using GENETYX version 7 program.

\section{DISCUSSION}

Identification of GH gene of P. hypophthalmus was done using tissue samples collected from pituitary, liver, muscle, brain, limph, and testes organs (Figure 1 ). Based on the results of the

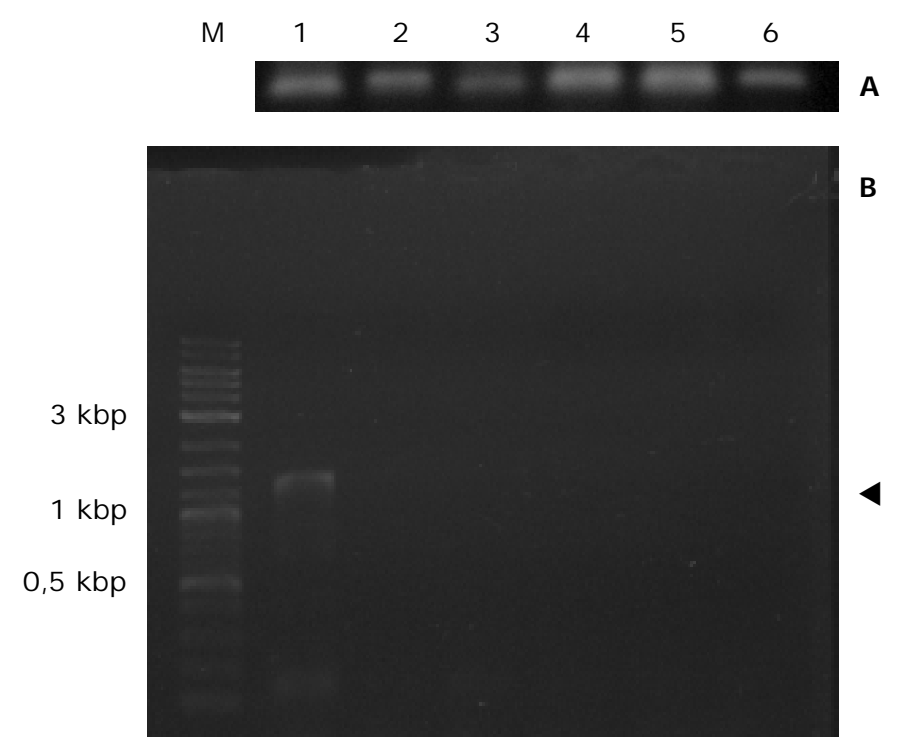

Figure 1. PCR products from some tissues using $\beta$-actin gene primer with fragment size of 200 bp (A). Result of PCR analysis from some tissues using FGHP and RGHP primer (B). M is DNA Marker (0.1-10.0 kb, BioLabs Inc., New England). 1= pituitary, 2= liver, $3=$ muscle, $4=$ brain, $5=\operatorname{limph}, 6=$ testes. Number in the left image is the size of DNA fragments Marker. Sign of the arrow (4) on the right shows the DNA target 
electrophoresis, GH gene was identified only in pituitary. $\beta$ - actin gene is used as the internal control. DNA band with a length approximately $1200 \mathrm{bp}$ is a candidate of GH gene fragment. DNA fragments were purified and then used as sample material for sequencing.

The full-length $\mathrm{GH}$ gene of $P$. hypophthalmus is 1,151 bp in length, coding for an open reading frame (ORF) of $603 \mathrm{bp}$. The $5^{\prime}$ and $3^{\prime}$ untranslated regions of the GH gene are 22 bp and 526 bp long, respectively (Figure 2). Amino acid translation is started with the ATG or sequence known as start codon which is symbolized in the form of methionin (M). Although stop codon is encoded by TAG sequence, it will not be translated into amino acid form, but instead it serves as signal sequence for the end of translation activity.

$\mathrm{GH}$ genes between species of fish vary in length. The length of $\mathrm{GH}$ gene in Pangasionodon gigas is 1,176 bp (accession: L27835; Lemaire et al., 1994), Cyprinus carpio's length is 1,164 bp (accession: M27000; Koren et al., 1989), Oncorhynchus keta's length is 1,120 bp (accession: K03050; Sekine et al., 1985), Oncorhynchus mykiss's length is 1,161 bp (accession: M24683; Rentier- Delrue et al., 1989a) and Oreochromis niloticus's length is 847 bp (accession: M26816; Rentier- Delrue et al., 1989b).

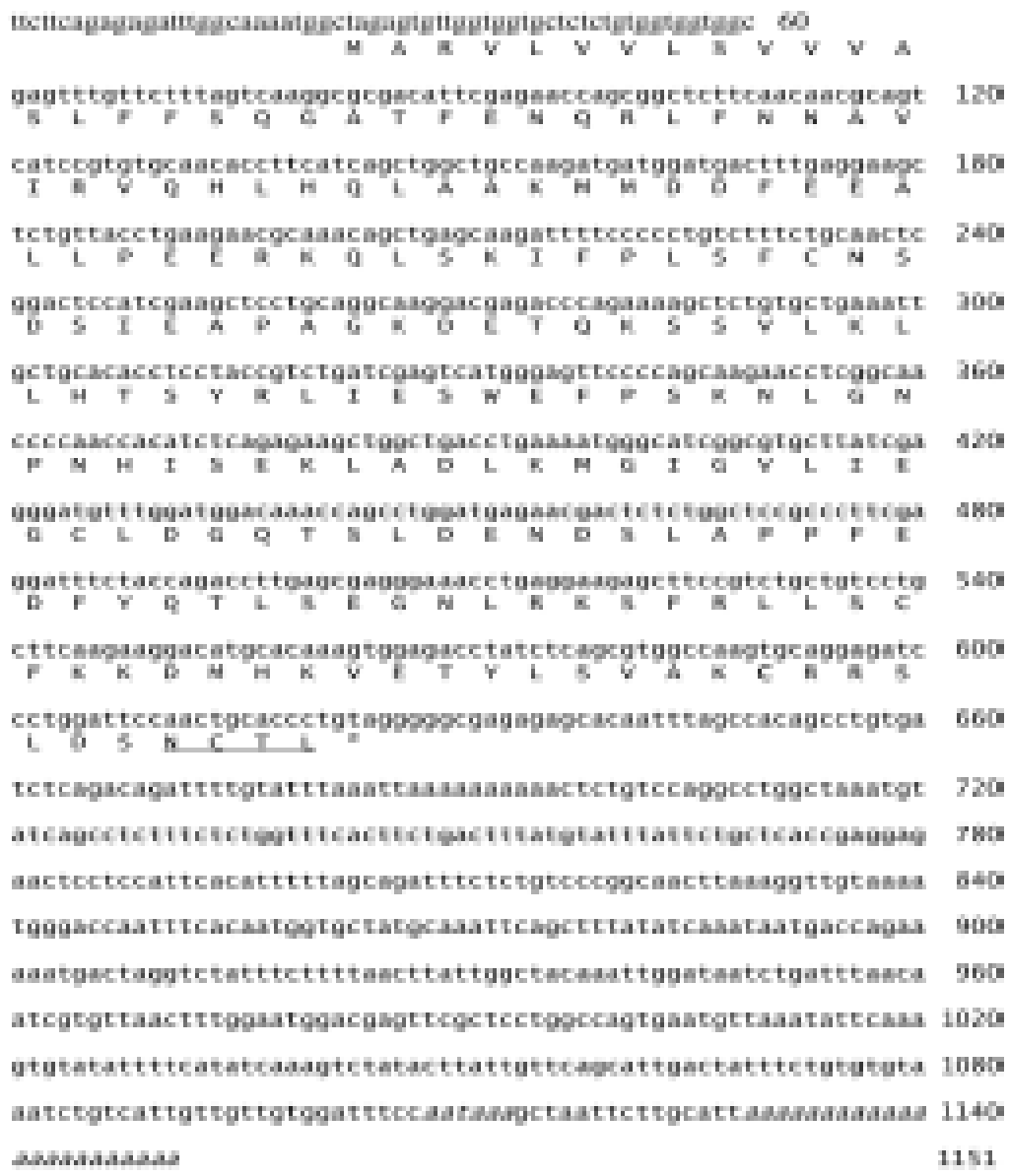

Figure 2. The complete nucleotide sequence of P. hypophthalmus. GH cDNA encoding the prepro GH peptide. The cDNA is 1151 long having a signal peptide of 22 residues and the mature peptide of 178 residues. Putative $\mathrm{N}$-glycosilation sites (Asn-Xaa-Thr/Ser) are underlined. The polyadenylation signal (aataaa) and the poly $A+$ are marked in italic letters 
P. hypophthalmus $\mathrm{GH}$ gene has some common characteristics that are exclusively owned by GH genes, such as a single tryptophan residue $(\mathrm{W})$ on the $104^{\text {th }}$ amino acid, 5 cysteine residues (C) on the amino acid 71, $135,173,190$, and 198 and a motif of Asn- XaaThr on $\mathrm{C}$ terminus which is the potential location for $\mathrm{N}$ - linked glycosilation. Polyadenylation signal (aataaa) was on the $14 \mathrm{bp}$ at the upstream of polyadenylation location.

Growth hormone is a polypeptide of fundamental importance for growth regulation in vertebrates and together with prolactin and somatolactin, constitutes a family of pituitary hormones with similar structure and function which appear to have originated from a common ancestral gene before the evolution of fishes (Kawauchi \& Yasuda, 1989 in Meier et al., 2006). GH has been found in all taxonomic groups of jawed vertebrates (gnathostomes) and, recently, also identified in sea lamprey, an extant representative of a group of the most ancient vertebrates (jawless vertebrates) (Rousseau \& Dufour, 2004).

Molecular data from nuclear genes such as the $\mathrm{GH}$ gene has been recently used as a source of information in order to evaluate evolutionary relationships of fishes at a variety of taxonomic levels, producing phylogenies with substantial statistical confidence (Meier et al., 2006). Analysis of nucleotide sequences is useful in studying relationship between sequences within different orders. The burst of evolution seen in $\mathrm{GH}$ evolution could be caused by a number of factors, including (1) altered selection pressure associated with changes in biological function, (2) relaxation of purifying selection due to loss of function, or (3) inadvertent comparison of the products of non-orthologous genes, following gene

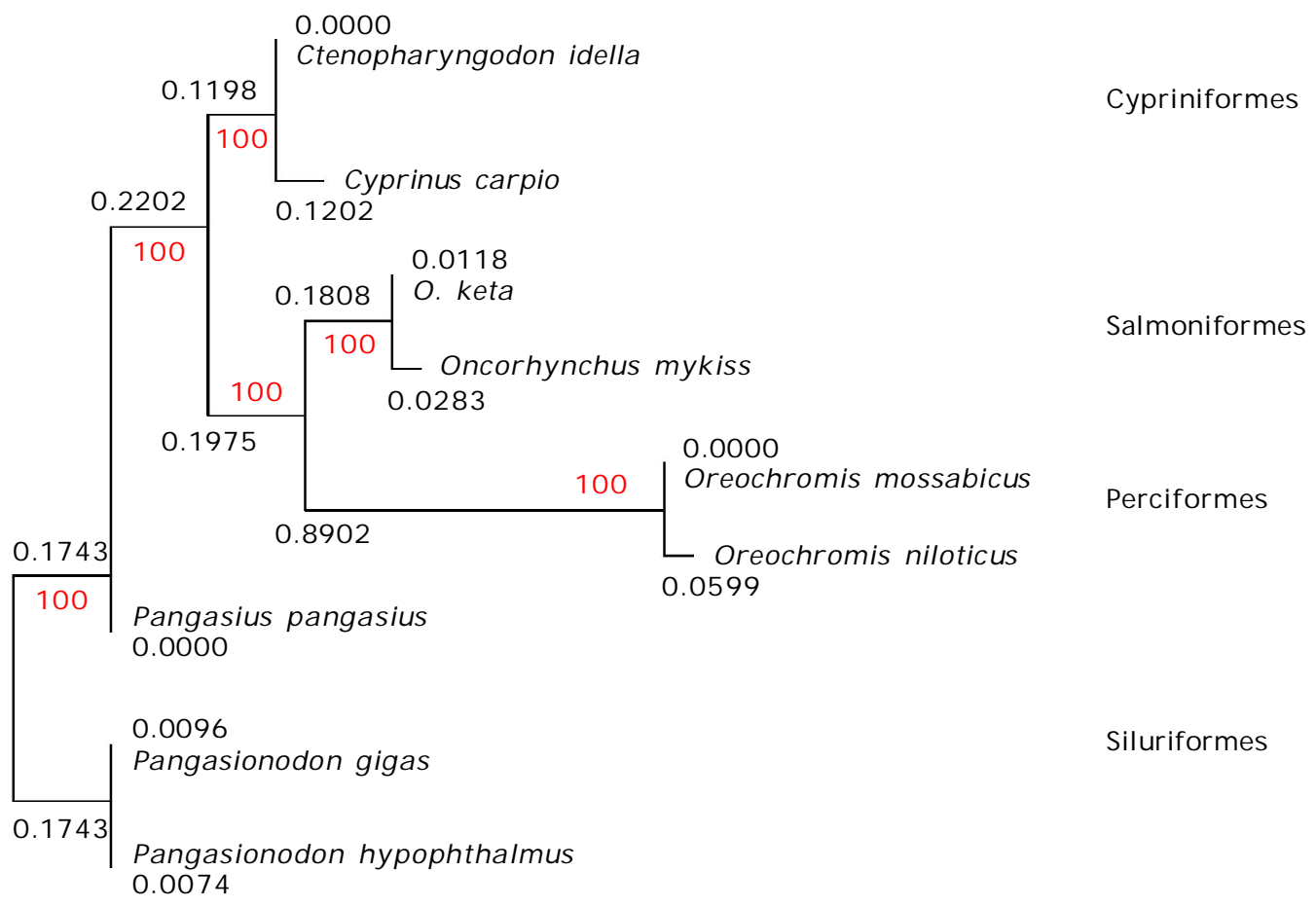

Figure 3. Phylogenetic tree based on nucleotide sequence of $\mathrm{GH}$ gene from 4 orders. Pangasionodon gigas (accession L27835; Lemaire et al., 1994), Pangasius pangasius (accession: M63713; Lemaire \& Panyim, 1991), Ctenopharyngodon idella (accession AY616661; Gong et al. , 2004), Cyprinus carpio (accession M27000; Koren et al., 1989), Oncorhynchus mykiss (accession M24683; Rentier- Delrue et al., 1989a), Oncorhynchus keta (accession K03050; Sekine et al., 1985), Oreochromis niloticus (accession M26916; Rentier- Delrue et al., 1989b), Oreochromis mossambicus (accession AF033805; Chen et al., 1997) 
Indonesian Aquaculture Journal Vol.4 No.1, 2009

duplication and long periods of divergent evolution (Wallis, 1996).

The consensus phylogenetic tree obtained (Figure 3) showed that P. hypophthalmus was in the same order with P. pangasius and P. gigas. Siluriformes has the highest nucleotide sequence homology with cypriniformes, while the lowest is perciformes.

The blastp analysis among 4 different orders can be seen in Figure 4. Homology of peptide sequences between P. hypophthalmus, $P$. gigas, and P. pangasius is $100 \%$ Based on nucleotide sequence, peptide deduction contains 200 amino acids consisting of 178 "mature peptides" and 22 amino acids of peptide signal. Anathy et al. (2001) reported that in fish including silurids, there were two locations of suspected $\mathrm{N}$ - glycosylation (Asn- XaaThror Ser), which normally resided in the amino acid- 125 and 175 in "mature peptide". Four cysteine residues were almost entirely in the

\begin{tabular}{|c|c|c|}
\hline \multicolumn{3}{|c|}{ 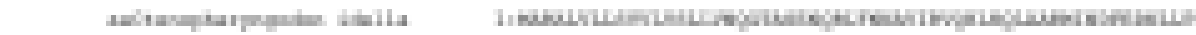 } \\
\hline 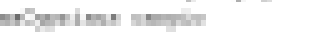 & 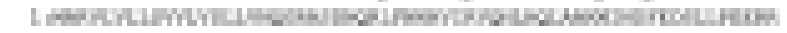 & An \\
\hline 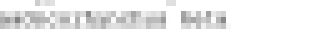 & 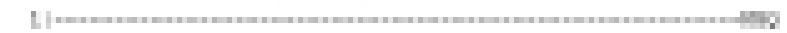 & 1 \\
\hline aimeobuha witim & 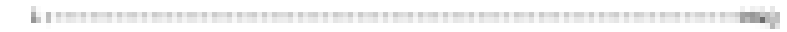 & i \\
\hline 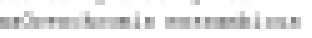 & 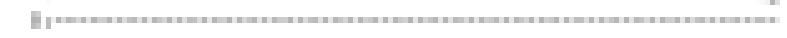 & \\
\hline 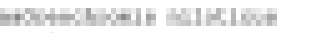 & 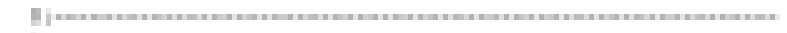 & \\
\hline 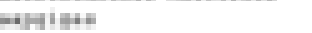 & 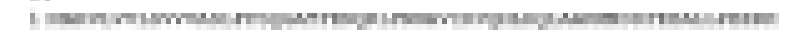 & ifit \\
\hline 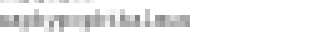 & 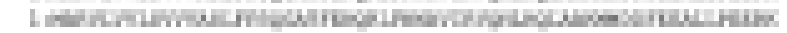 & Is: \\
\hline \multirow[t]{2}{*}{ mitringin } & 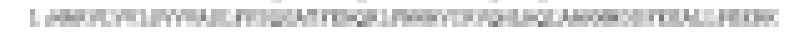 & H \\
\hline & 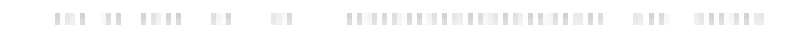 & \\
\hline 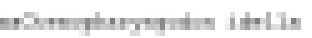 & 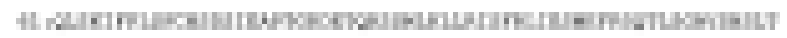 & 11: \\
\hline 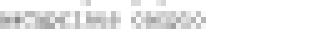 & 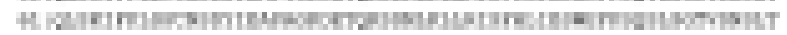 & \\
\hline 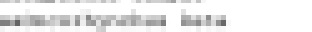 & 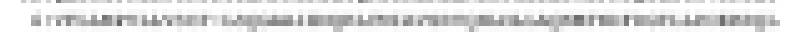 & 1.4. \\
\hline 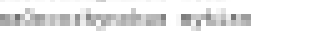 & 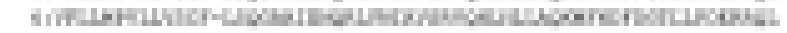 & H: \\
\hline 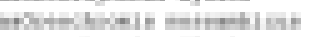 & 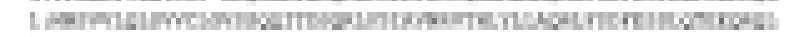 & 4 \\
\hline 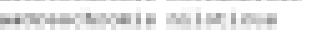 & 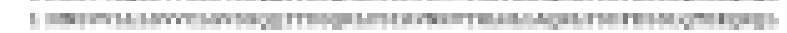 & ait \\
\hline animi & 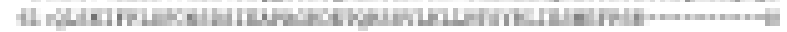 & 11: \\
\hline 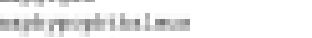 & 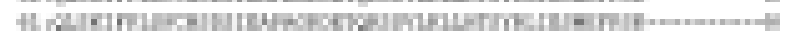 & 111. \\
\hline 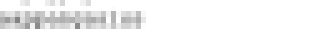 & 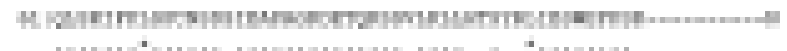 & 111 \\
\hline 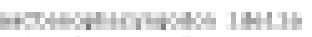 & 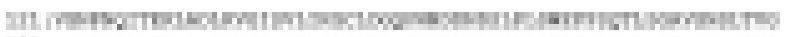 & III \\
\hline 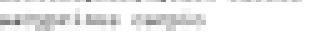 & 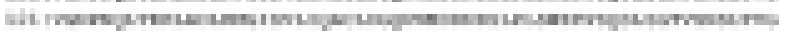 & iti \\
\hline minumbuthe his & 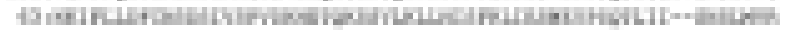 & Til \\
\hline 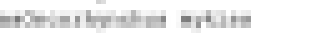 & 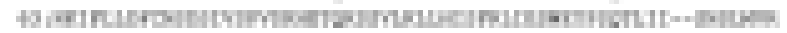 & 111 \\
\hline 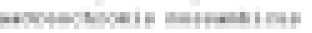 & 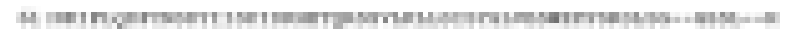 & 114 \\
\hline ahrobnin minime & 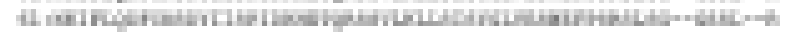 & III \\
\hline minte & 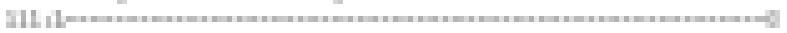 & 11: \\
\hline Humplates & 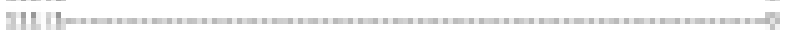 & III \\
\hline \multirow[t]{2}{*}{ Hipupaim } & 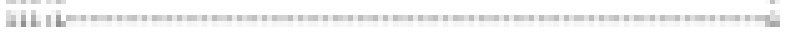 & \\
\hline & " "- " " = & \\
\hline 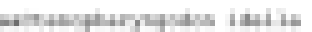 & 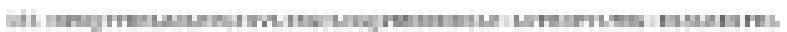 & \\
\hline whine ming & 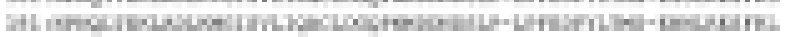 & $1 \mathrm{II}$ \\
\hline 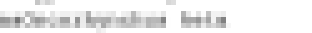 & 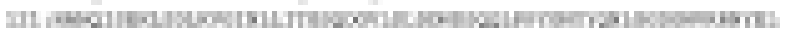 & III \\
\hline 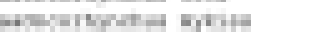 & ait mongh & 110 \\
\hline 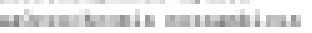 & 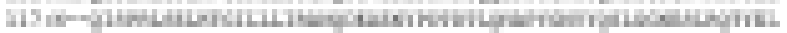 & 1:H \\
\hline mantentrein maltime & 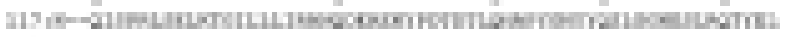 & 114 \\
\hline HНाнस & 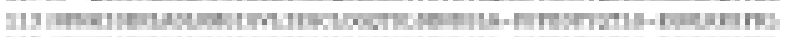 & $1 \mathrm{r}$ \\
\hline athpinglas & 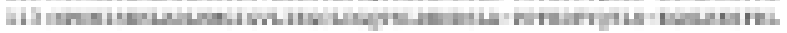 & 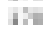 \\
\hline mpropine & 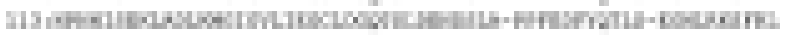 & Iiti \\
\hline & 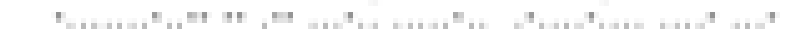 & \\
\hline 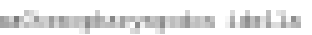 & 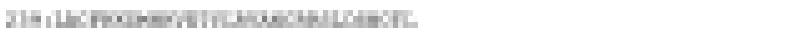 & Iit \\
\hline 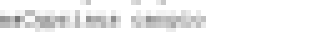 & 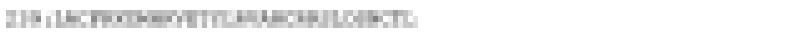 & 1 \\
\hline 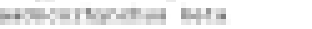 & 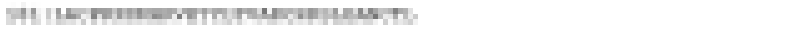 & 110 \\
\hline 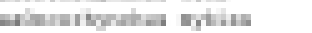 & 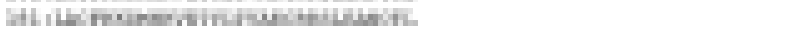 & III \\
\hline 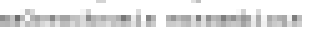 & 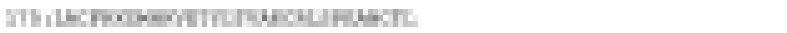 & 34 \\
\hline 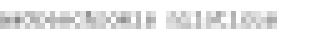 & 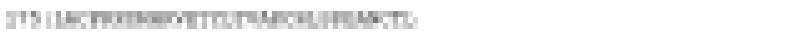 & 174 \\
\hline aнінін & 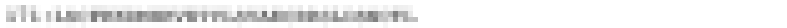 & Itili \\
\hline moth intrina & 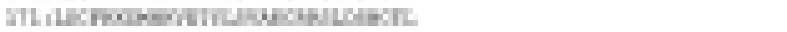 & בhII \\
\hline mintrint & 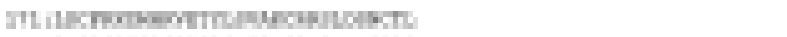 & 14 \\
\hline
\end{tabular}

Figure 4. Comparison of $\mathrm{GH}$ peptide sequence on 4 different orders 
"mature peptide" with a position that was identical to the amino acid- 49, 113, 151, and 178.

Ryynanen \& Primmer (2006) reported the putative signal peptide region was predicted to include the first 22 amino acids in all teleosts (salmoniformes, siluriformes and cypriniformes) pre- $\mathrm{GH}$ proteins, with the exception of those in perciformes, which consisted of the first 17 or 18 residues depending on the species. The $\mathrm{C}$ - terminal region is highly conserved among all teleost fishes containing 3 out of 4 cysteine residues known to be important for disulfide bonds formation. The existence of bonds is important for structural integrity and hormone biological activity. The fourth conserved cysteine was in position 71 (72 in perciformes). Putative functionally important sites of teleost $\mathrm{GH}$ were also relatively conserved when they were compared to other mammalian $\mathrm{GH}$ sequences (Liu et al., 2001). Over 30\% of the reported sites in mammals were identical to fish amino acids and $54 \%$ of the sites in teleost were similar to at least one mammalian species.

P. hypophthalmus growth hormone is arranged by over 200 amino acids which are encoded by 20 types of amino acids (Figure $5)$. The highest amino acid composition is leusin $(14 \%$ while the lowest is tryptophan $(0.5 \%$. Syaifudin (2006) reported that the GH gene from Cromileptes altivelis cDNA was arranged by 205 amino acids among which the highest composition was leusin (14.63\%) and Serin $(12.20 \%$ and the lowest was tryptophan $(0.49 \%$. These 20 amino acids of this protein were joined by peptide bond (NRC, 1993).
Protein requirement of fish must contain sufficient quantity of 10 essential amino acids (fish can not afford synthetics). These amino acids are important for tissues protein synthesis. GH amino acid composition can be used as a reference in the preparation of feed formulation for P. hypophthalmus.

\section{CONCLUSION}

The full-length $\mathrm{GH}$ gene of $\mathrm{P}$. hypophthalmus is $1,151 \mathrm{bp}$ in length, coding for an open reading frame (ORF) of $603 \mathrm{bp}$. The $5^{\prime}$ and 3' untranslated regions of the GH gene are $22 \mathrm{bp}$ and $526 \mathrm{bp}$ long, respectively. P. hypophthalmus GH gene has some common characteristics that are exclusively owned by GH genes, such as single tryptophan residue (W) on the $104^{\text {th }}$ amino acid, 5 cysteine residues $(C)$ on the amino acids of $71,135,173$, 190, and 198 and a motif of Asn- Xaa- Thr on C terminus which is the potential location for $\mathrm{N}$ linked glycosilation. Polyadenylation signal (aataaa) was on the $14 \mathrm{bp}$ at the upstream of polyadenylation location. Growth hormone P. hypophthalmus was arranged by over 200 amino acids from GH cDNA deduction. The highest proportion of amino acid composition was leusin $(14 \%$ while the lowest was tryptophan $(0.5 \%$.

\section{REFERENCES}

Anathy, V., Venugopal, T., Koteeswaran, R., Pandian, T.J., \& Mathavan, S. 2001. Cloning, sequencing and expression of cDNA encoding growth hormone from Indian cat-

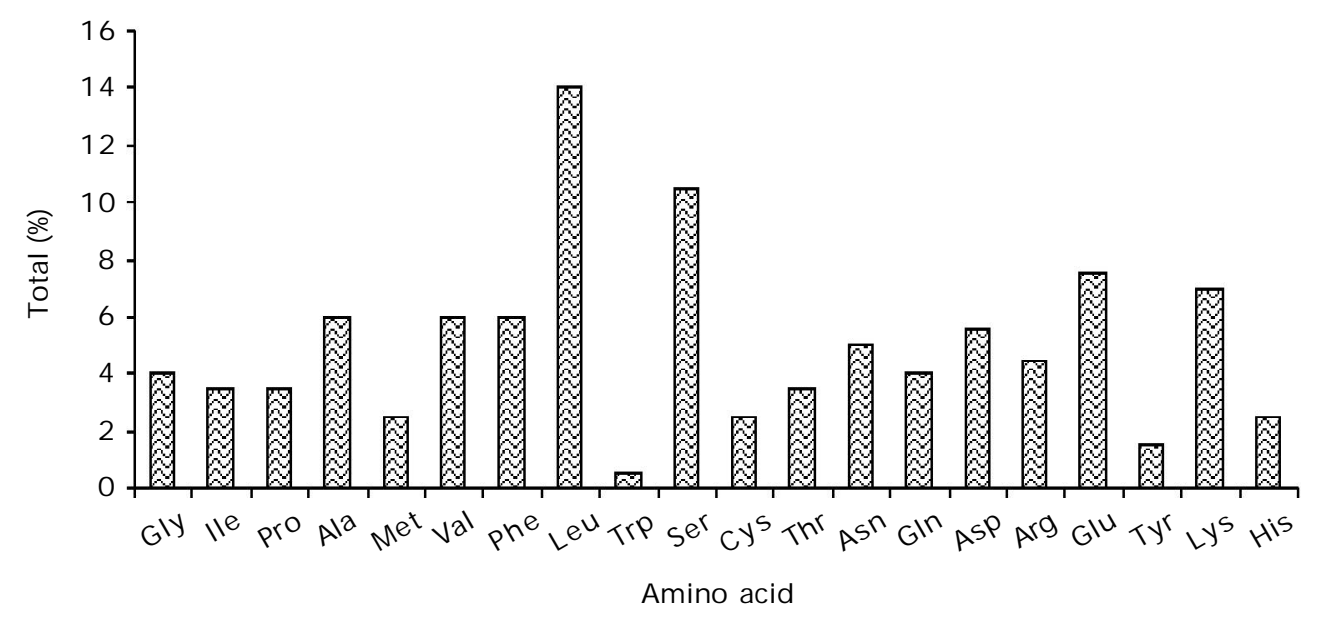

Figure 5. Amino acid composition of P. hypophthalmus growth hormone 
fish (Heteropneustes fossilis). Journal Biosciences, 26(3): 315- 324.

Chen, J.Y., Chang, C.Y., Shen, S.C., Wang, J.I., \& $\mathrm{Wu}$, J.L. 1997. Production of recombinant Oreochromis mossambicus growth hormone (GH) polypeptides in E. coli cells and characterization of the molecular structure of the GH gene. GeneBank accession number AF 033805.

Devlin, R.H., Yesaki, T.Y., Donaldson, E.M., Du, S.J., \& Hew, C.L. 1994. Production of germline transgenic pacific salmonids with dramatically increased growth performance. Canadian Journal of Fisheries Aquatic Sciences, 52: 1,376-1,384.

Devlin, R.H., Biagi, C.A., Yesaki, T.Y., Smailus, D.E., \& Byatt, J.C. 2001. Growth of domesticated transgenic fish-growth hormone transgene boosts the size of wild but not domesticated trout. Nature, 409: 781- 782.

Du, S.J., Gong, Z., Fletcher, G.L., Shears, M.A., King, M.J., Idler, D.R., \& Hew, C.L. 1992. Growth enhancement in transgenic Atlantic salmon by the use of an "all fish" chimeric growth hormone gene construct. Bio/Technology, 10: 176- 180.

Dunham, R.A., Eash, J., Askin, J., \&Townes, T.M. 1987. Transfer of metallothionein- human growth hormone fusion gene into channel catfish. Trans.Am. Fish.Soc., 116: 87- 91.

Gong, C., Cao, G., Xue, R., \& Yang, Y. 2004. GeneBank accession number AY616661.

Koren, Y., Sarid, S., Ber, R., \& Daniel, V. 1989. Carp growth hormone: molecular cloning and sequencing of cDNA. Gene, 77(2): 309315.

Lemaire, C. \& Panyim, S. 1991. Pangasius pangasius growth hormone mRNA complete coding sequence. GeneBank accesion number M63713.

Lemaire, C., Writ, S., \& Panyim, S. 1994. Giant catfish Pangasionodon gigas growth hormone encoding cDNA cloning and sequencing by one sided polymerase chain reaction, Gene, 49: 271- 276.

Liu, J.C., Makova, K.D., Adkins, R.M., Gibson, S. \& Li., W.H. 2001. Episodic evolution of growth hormone in primates and emergence of the species specifity of human growth hormone receptor. Mol.Biol.Evol., 18: 945- 953.

Martinez, R., Estrada, M.P., Berlanga, J., Guillen, I., Hernandez, O., Cabrera, E., Pimentel, R., Morales, R., Herrera, F., Morales, A., Pina,
J.C., Abad, Z., Sanchez, V., Melamed, P., Lleonart, R., \& de la Fuente, J. 1996. Growth enhancement in transgenic tilapia by ectopic expression of tilapia growth hormone. Mol.Mar. Biol. Biotech., 5: 62- 70.

Meier, K.M., C. Castano, J. Laurino, J.A. Levy, and L.F. Marins. 2006. cDNA cloning and phylogenetic analysis of growth hormone genes from the mullet Mugil platanus (Mugilomorpha, mugilidae) and the halfbeak Hemirhamphus brasiliensis (Atherinomorpha, Hemiramphidae). Atlantica, Rio Grande, 28(2): 97- 102.

Nam, Y.K., J.K. Noh, Y.S. Cho, Cho, H.J., Cho, K.N., Kim, G., \& Kim, D.S. 2001. Dramatically accelerated growth and extraordinary gigantism of transgenic mud loach Misgurnus mizolepis. Transgenic Research, 10:353362.

Nasution Z, Dharyati, E., \& Rupawan. 1997. Adopsi teknologi budidaya ikan patin pada masyarakat tani di Desa Mariana, Sumatera Selatan. Jurnal Penelitian Perikanan Indonesia, 3(2): 35- 40.

NRC (National Research Council). 1993. Nutrient requirement of fishes. National Academy Press, Washington DC, 114 pp.

Pitkanen, T.I., Krasnov, A., Teerijoki, H. \&Molsa, H. 1999. Transfer of growth hormone (GH) transgenes into Arctic charr (Salvelinus alpinus L.). I. Growth response to various GH construct. Genet. Anal. Biomol Eng., 15: 99- 105.

Perez-Sanchez, J. 2000. The involvement of growth hormone in growth regulation, energy homeostasis and immune function in the gilthead sea bream (Sparus aurata): a short review. Fish Physiology and Biochemistry, 22: 135- 144.

Rentier-Delrue, F., Swennen, D., Mercier, L., Lion, M., Benrubi, O., \& Martial, J.A. 1989a. Molecular cloning and characterization of two form of trout growth hormone cDNA, expression and secretion of $\mathrm{tGH}$ - II by Escherichia coli. DNA, 8(2): 109- 117.

Rentier- Delrue, F., Swennen, D., Philippart, J.C., L'Hoir, C., Lion, M., Benrubi, O., \& Martial, J.A. 1989b. Tilapia growth hormone: molecular cloning of cDNA and expression in Escherichia coli. DNA, 8(4): 271- 278.

Rousseau, K. \& Dufour, S. 2004. Phylogenetic evolution of the neuroendocrine control of growth hormone: contribution from teleost. Cybium, 28(3): 181- 198.

Ryynanen, H.J. \& Primmer, C.R. 2006. Varying 
signals of the effects of natural selection during teleost growth hormone gene evolution. Genome, 49: 42- 53.

Sekine, S., Mizukami, T., Nishi, T., Kuwana, Y., Saito, A., Sato, M., Itoh, S., \& Kawauchi, H. 1985. Cloning and expression of cDNA for salmon growth hormone in Escherichia coli. Proc.Natl.Acad.Sci.USA, 82(13): 4,3064,310.

Syaifudin, M. 2006. Isolasi dan karakterisasi cDNA hormon pertumbuhan ikan kerapu bebek (Cromileptes altivelis). Thesis
Sekolah Pascasarjana, Institut Pertanian Bogor, $63 \mathrm{hlm}$.

Wallis, M. 1996. The molecular evolution of vertebrate growth hormones : a pattern of near- stasis interrupted by sustained burst of rapid change. Journal of Molecular Evolution, 43: 93- 100.

Zhu, Z. 1992. Generation of fast growing transgenic fish: methods and mechanism. In Hew CL, and Fletcher GL (eds). Transgenic fish, p. 99- 119. World Scientific, Singapore. 